\title{
Student Housing a Resilient Housing Rental Market: Case of Federal Polytechnic Neighbourhood Bauchi, Nigeria
}

\author{
Zubairu Abubakar Ghani ${ }^{1,2}$, Noralfishah Sulaiman ${ }^{2}$, Mohammed Ishaq Mohammed ${ }^{1}$ \\ ${ }^{1}$ Abubakar Tafawa Balewa University \\ Tawafa Belewa Way, P. M. B. 0248, Bauchi, 740272, Nigeria \\ ${ }^{2}$ Universiti Tun Hussein Onn Malaysia \\ 101 Parit Raja, Batu Pahat, Johor, 86400, Malaysia
}

DOI: $10.22178 /$ pos.32-7

JEL Classification: 018

Received 10.02.2018

Accepted 02.03.2018

Published online 10.03.2018

Corresponding Author:

Zubairu Abubakar Ghani,

zubairughani@yahoo.co.uk

(C) 2018 The Authors. This article

is licensed under a Creative

Commons Attribution 4.0

License @ ()

\begin{abstract}
In the last three decades globally higher institutions (HIs) have been experiencing an unprecedented upsurge in student population and student enrolment in His generally outstrip the Hls student housing. In many countries of the world like Nigeria, Hls are obviously incapacitated in accommodating the growing student population which compelled numerous students to overflow into their HIs' neighbourhood seeking for alternative housing accommodation in the private housing rental market. Indeed the scenario of Hls student's housing shortfalls and increasing students housing demand evolved the interest of many people in a student housing rental market. This is because it has been uncovered that business in student housing rental is lucrative and guaranteeing business that ensured profit for a long term. This paper, therefore, explores the nature and landscape of student housing rental in Nigeria where the business is immature then drawn the conclusion.
\end{abstract}

Keywords: student housing; higher institution; private rental market; student housing demand; return; resilient.

\section{INTRODUCTION}

Colleges of higher learning experienced unprecedented high growth in student population as enrolment increases more especially in the last three decades in many countries across the globe. It is obviously clear student enrolment in higher institutions (HIs) are growing tremendously all over the world more especially in the UK, USA, Ireland, China, India, Nigeria, Ghana and Nairobi [4, 5, 9, 10, 21, 22, 29, 32, 34, 42, 50]. Increasing enrolment of students in HIs is not matching with the students housing supply and HIs are finding it tough to accommodate all students in their existing housing facilities therefore necessitated pushing some students out to opt for alternate student housing options in the open housing market. Similarly [30] supported this assertion that inability of HIs to expand their student accommodation to sufficiently accommodate the enrolled student population has increased housing demand in rental market in HIs neighbourhoods. Similarly, [49] opined that astronomical growth of students' population initiates pressure on HIs students' housing facilities and inadequate to accommodate the teaming student population. Likewise [34] summarized the situation of HIs students housing shortfalls that the student population increase, has run ahead of the ability of HIs to house them and has led to a growing reliance on the private rental market. HI maintained a traditional housing accommodation for few students while majority had to rely on the private rental market [43]. These are indications that student housing is grossly inadequate in most HIs in both developed and developing countries as the population of students keep on growing thereby creating demand in the private rental market.

The aim of this paper is to highlight the student housing rental market potentials and to pull the interest of private developers and business people to participate actively in student housing 
provision. This is because they will play major role in supplementing and filling the gap created by HIs student housing shortfalls in providing housing accommodation to the majority of HIs students. It deems necessary and a major concern for both HIs and governments by inviting private developers to provide students housing hence government and or HIs cannot provide adequately. This has led to many landlords and letting agencies in HI towns throughout the UK, to acquire properties suitable for renting to students in areas close to HIs [35].

\section{Student housing related studies}

Traditionally in Nigeria during the 1960 through early 1980, student housing was exclusively the responsibilities of HIs then all student accommodations were adequate and on-campus. However, afterward student population begins to upsurge beyond HIs housing capacity which gave birth to rental off-campus student housing in HIs neighbourhoods. Due to HIs sufficient deficits of student housing, students are compelled to opt for alternative housing and created demand in the private rental markets in HI towns. Equally, $[4,3]$ confirmed that on-campus students' housing is overstretch and grossly inadequate in $\mathrm{Ni}$ gerian universities. Therefore, in such a situation, students could live in any type of housing unit that is available in the HI neighbourhood as an option for their housing. In trying to fill up the gap, to some extent some family residential owners let the apartments to students. In this situation some studies reported, most of the students rented houses are family residential converted to students houses $[2,4,5,8,10,15,16,19,21,24$, $28,30,34,36,40,42,49,50$,). Likewise [4] in his study in Nairobi found that, over $70 \%$ of rented student houses in the HIs neighbourhoods are family houses converted to students housing and [24] in their study confirmed that students in offcampus housing are living in family housing like apartment, condominium, terrace, semi-detached and detached houses. That is why in many places, it is a common practice to change the structure of these houses to increase the number of separate units and single rooms for maximising the economic gains of the landlords [45].

High HIs student population growth, couple with limited housing facilities led to high demand for students housing and the birth of private students housing rental market around HIs neighbourhoods globally. In this regard, private developers and business people are the key players in the provision of students housing as they accommodate majority of the HIs students and their roles is highly significant not only to students but to the government and HI as well since it warrant continuous development of educational sector and expansion of HIs. Correspondingly [16] reported, in the current trends, the private sector provides more than $50 \%$ of what are understood to be HIs halls of residence.

As the result of insufficient $\mathrm{HI}$ housing for students, some HIs give priority to newly admitted, final year and female students on the basis of their housing capacities or else on the basis of 'first-come first-serve' can only get HI housing accommodation. While sophomores and upper levels students have no option rather than to relied on the private sector market in the HIs neighbourhoods. Many studies such as [5, 9, 10, $16,19,25,26,34,42,43,46,49]$ have reported the shortage of HIs housing facilities with increasing enrolments warranted many HIs reserving on-campus houses for first-year and final year students while upper-class students are often forced into the local communities. On average a student stays in a traditional HIs hall of resident for barely one academic year and the remaining years are spent in private student houses in offcampus to make way for the next batch of students.

Over the past decades students housing rental market has emerged as main stream rental market category, attracting significant interest from individuals, developers and private letting managers. The students housing rental market hasty growth was underpinned by the active rise in student population and demand for higher education (HE) worldwide [16, 18]. In addition to local students demand, also there is significant increase in international students influx in English speaking countries, chiefly the US and the UK, have been the biggest recipients of these students, which led the way to emergence of student housing rental market to meet up with the growing demand. Subsequently, they have become the most developed of all the global student housing rental markets [39]. Furthermore, [38] reported that 'the US stands out as the most mature student housing rental market followed by the UK as the next most mature market the sector has undergone hasty development especially during the last three decades and has even maintained momentum during recession period [16, 37, 38, 39, 43]. Consequently, private student housing has 
become one of the easy-going, proving relatively resilient market and profitable venture for property business in the UK and USA. Similarly, [16] summarized the situation that in the last five years UK has witnessed a revolution in the supply of the student housing. In HIs towns throughout UK, both individual landlords and letting agencies have accordingly sought properties suitable for conversion to student housing in areas close to HIs. This largely outcompete lowincome families seeking similar houses for renting and/or buying [16, 35]. Equally, [30] reported that private student housing provision is a competitively high returning asset and experienced stable economy around HIs then conclude that in recent years there are significant development of private hostels around HIs in Nigeria.

Eventually this led to provision of Purpose Built Student Housing (PBSH) which has increased considerably over the last decade and has played an important role in meeting the demands of both students and the HIs in UK. Furthermore, these privately managed PBSH offer variety room types for students' choice; en-suite rooms with double beds, single sharing, double sharing and apartments of 2 or 3 rooms, flat screen TV, highspeed internet networks connections and free wireless broadband, launderettes, as well as CCTV coverage around the building to appeal to security-conscious students $[11,43]$. Many privately-owned student housing developers are offering attractive housing options, the overall quality of new private sector student housing is continuing to rise over the old traditional student housing, en-suite housing facilities are now considered standard in most student houses and such developments are considered the solution to accommodation deficiencies in HIs towns especially in the UK [16].

Equally, this new scenario of PBSH led to the development of new and better students housing across Europe and USA which also forced the private sector market particularly the traditional student housing providers to up their business in terms of providing better quality housing. To some extent, also forced out a lot of the small buy-to-let type of landlords who will just buy a house for renting out to students and it has also forced out some of the rogue landlords that have substandard houses [43]. This appears to have increased expectations and landlords are less able to get away with sub-standard houses. Thus, students attach priority to different dimensions of housing quality in their decision to rent house and students would evaluate the important they attach to the core facility, enabling facility, supporting facility, cost and overall quality of the housing. However, the distinct quality of students housing found in PBSH appeared to play a decisive role in the choice of PBSH rather than the traditional private student housing market where such quality is not usually available [11]. Therefore, it is of paramount importance for private sector providers seeking to attract more students to their housing, should offer a 'product' that is more satisfactory and attractive to students $[19,43,49]$.

Student housing rental market proliferation is a recent phenomenon in the arena of rental market due to student population explosion across the world and incapacitation of HIs to provide adequate accommodation for the teaming enrolment. Also [47] observed that Nigeria's HE sector has been overburdened by strong population growth with significant youth bulge where more than $60 \%$ of the population ( $\$ 190.9$ million) is under the age of 24 years old. According to [31] about $44 \%$ of the total population is under the age of 15 years old, therefore these can be translated into future potential for HIs student population growth and student housing demand. This resulted to number of applicants seeking placement in universities currently exceed the available accommodation and pushed housing demand in the rental market at their HI neighbourhoods.

The market according to [38] is only considered matured in places like USA, UK, Germany and Island; developing in countries like Italy, Netherlands, Spain and Australia and is yet to be recognize and develop as viable market in most of the developing nations. The market in countries where it is matured is different from most other rental types with guaranteed demand, returns and is resilient which makes it attractive. The world student housing rental sector investment grew from $\$ 0.8$ billion globally in 2009 and rapidly to a high of $\$ 7.2$ billion in 2013. Mainly the US and UK markets have driven global investment in student housing to reaching this elevation.

European student housing rental market proposed gross average yields range from $5.5 \%$ to $8.5 \%$ for prime property. It was observed that major achievable yields in the sector are in the region of $7 \%$ in Italy, the Netherlands, and Spain, $[37,39]$. Equally, [17] observed and reported in 
UK study that, student housing rental market experienced annual rental growth of $1.6 \%$ in 2013 and it is predicted to increase to $2.8 \%$ in 2014 . Likewise [36] observed that in Europe, central London in particular, is the major location for students housing and the total return of $6.7 \%$ between 2010 and 2011 for PBSH. Furthermore, returns from student property have been examined to have outperformed all other property sectors since 2011 and student property index recorded total returns of $7.8 \%$ for the year 2013, $10.9 \%$ in 2014 while, all other properties recorded $5.4 \%$ growth; while residential rental rates in particular have remained relatively stagnant in 2013.

In recent years, in Germany student housing rental market, investors' interest has been growing and the sector saw tremendous growth in 2013 with over 7,600 units planned in the top ranking university cities. The average PBSH provision rate among the key cities is $13 \%$ and vacancy rates have declined to below $2 \%$ [37]. Equally, in Australia, Singapore and India the phenomenon seems to be surging considerably within their student housing rental sectors, though the market is still considered 'immature' when compared to that of the UK and US $[9,20]$. According to [9], recently in India, Manipal Integrated Services, build and manage student housings complex in Bangalore with 1,000 rooms to provide housing to around 2,000 students.

Private developers' interest in student housing rental market is not surprising given that student housing has been considered as the fastest growing sector of the rental market and the demand appears to be guaranteed proven. Student housing rental sector offers relatively high yields compared to other property sectors like retails, warehouses and offices. Profit yields have moved rapidly over the last decade in the wider rental market and income returns in the sector exceeded the residential rental market [38, 39]. Similarly, it was observed that, student housing was one of the best performing sectors during the global economic downturn $[13,39,50]$ and unlike the apartment sector, it is largely unaffected by falling home market prices and nearby company layoffs will not affect demand. As such a well-located student housing should have lower volatility than multifamily and provides somewhat a higher cash return. Student housing is now considered a valuable, global asset class therefore, investors generally, are looking for more generous yielding sectors compared to others for their investment. Consequently, [16] deemed commercial operators to have been extremely active over the last five years, expanding by acquiring more stocks, as well as, funding speculative developments in higher education institutions towns.

In term of practice, the leading student housing market are the UK and USA, where students have several options available to them because the market is matured, as in contrast to many other countries. Due to the inadequacy of HIs' owned residence halls, the private developers have taken a great advantage of students demand and are driven into the student housing market not only in the UK and the US, but in many other countries including Nigeria. According to [44] survey of 20 private students house developers in USA found that, in 2015 alone, these companies have over 167 student properties under construction comprising 97,045 beds. This is because, it is a distinct niche market for private developers and home-owners more especially those who would target areas adjacent to HIs campuses $[6,8,12,36]$ hence, the waves of student demand tells much about the likelihood of the better place of opportunity.

\section{METHODOLOGY}

Methodology adapted in this study is qualitative study being is important in the behavioural (social) sciences where the aim is to discover or investigate the causal motives for human behaviour or attitude perceptions in order to gain understanding of social and human activities [7, 41, 48]. It permit the use of one or combination of research instruments such as interviews, documents, observation and audio-visual materials as suggested by $[7,14]$.

However, data generated in this research is through expert interviews on a basis of face-toface interpersonal interactions with respondents as suggested by [23, 27, 33]. Drawing the respondents was based on purposive because they are homogeneous being all of them are student housing providers (landlords) in the study area and will enable detailed understanding of student housing rental market. Furthermore, opportunistic approach was adopted in picking the respondents on the basis of their availability and willingness to participate in the research interviews $[1,33]$. 


\section{RESULTS AND DISCUSSION}

The rising demand of higher education has increased the tempo of student demands and is the driver for student housing demand. It becomes clear HIs housing system is grossly inadequate to satisfy the growing demands. Therefore, filling the gap created by shortage of HIs housing system, lays in the hands of other HIs stakeholders Visa-vies the private housing rental market and private developers around the HIs. As a result of HIs inability to provide sufficient students housing, governments in many countries have required private student housing providers to participate in building hostels and halls of residence for students in order to meet up the growing demand for more housing infrastructure. This has attracted many private individuals into student housing rental market even in the developing countries where the market is not yet fully developed. In Nigeria this phenomenon started around late 1980 when student population began to upsurge beyond HIs housing capabilities which witness the commencement of off-campus rental student housing in HIs neighbourhoods across the country.

"I started when a defaulting family tenant was evicted from my house and then students rent it. Yes, then I realised that it is money-spinning and students are not defaulting payment" (Participant 3).

"Well, I am sure ah yeah, student rental, for sure, is rewarding. You know students at the beginning of their study year they came with a lot of money so they can pay rent for say six months or one year. So this is rewarding" (Participant 1).

"Students are good tenants they pay rent at once which give you high income. Ah yes, student rental is beneficial to me because I get my rent complete and enable me settle my children's school fees and do other things. I think is good and ok" (Participant 2).

It has been established that, private off-campus student housing in the US and UK is a lucrative business with rent growth of $7 \%$ rates between 2004 and 2006. This is because of the high level of student demand for rental properties that guaranteed high rates of return and low void
Many scholars have reported that, student housing market is lucrative and promising business that guaranteed return for a long term investment and income returns generated in the sector generally exceed the residential investment market as a whole. In recent years it has been identified that student housing is one of the most vibrant rental markets in the developed nations and also foreseen to be flamboyant in future in developing countries. Dense student populations that exist around prominent HIs positively affect the demand for residential spaces in HIs towns. In fact, the future of this sector is expected to be extremely promising hence HIs population cohort is great and high demand for HE. In similar studies in Nigeria confirmed that, private hostel accommodation provision is proliferating around HIs neighbourhoods with a competitively high returning asset. Similarly, student housing is becoming one of the most important industry that generate income and produce job opportunities. Students housing niche is lucrative not only in the developed countries like the US and UK, but also in the developing nations the scenario is the same. rates, making students' rental an attractive business option in universities neighbourhoods. The sector is undergoing rapid growth, proving relatively resilient market and seems to be fairly recession-proof as students keep on enrolling in HIs.

"Yes economy now is hard but students keep on coming to rent houses and most of them pay upfront for the year or six months. I don't really have problem with it because they pay. You know parents now really support their children to study" (Participant 1).

"Ah precisely talking on students' rental, I think is very good, despite current economic meltdown students manage to pay rent only few of them will pay for semester period may be 3 or 4 months and I do consider the situation, they are trying" (Participant 2).

"Yes, I agreed with you economic situation is affluent couple with inflation, but to my surprise students manage to pay rent for at least 3-6 months. I think student rental is ok better than family tenants, no defaulting" (Participant 3). 
As it has been said, student housing has consistently been one of the best performing sector during the global economic downturn. Student housing produces reliable rental income flow which, although derived from short tenancies (one year), is secured by intensity and stability of demand, and often matched by low levels of competing supply. In addition, student housing properties experiencing low incidence of empty (void) room; this may not be unconnected to low supply and competing demand. Landlords who rent their houses to students are more likely to find tenants and receive rent on time, hence students are worthy tenants, pay upfront, and had no problems with rental payment. As a result, many landlords prefer students over families because, if family tenants fail to pay, it is more difficult to evict family defaulters. It is an attractive rental business option, promising returns and offers guaranteed long-term income streams.

"You know students come and go, so they usually pay for rent at the beginning of a session for a year or 6 month, mostly they are not difficult in paying rent. Students are good tenants, they don't normally complain on rent unlike family tenant. Ah for the last 3 years in my experience, there was no time I have empty room" (Participant 3).

"It is much easier to rent your house to students, because they pay on time hardly default payment. Ah the occupancy is high with no empty rooms because student prepared to be close to their school and they are competing to get accommodation here and we don't have enough for them" (Participant 2).

"Yes, as I told you since I started with students I didn't rent my house to family tenant again because I enjoyed students' tenancy. Ah yeah, I am lucky because my location is close to the school just across the road, so for some years now no void in my house. You know students are competing to get accommodation close to school, this is my advantage" (Participant 1)

The high level of student demand for rental houses will guaranteed good return rates and low void rates, therefore, targeting students housing rental at densely student HI neighbourhoods is an attractive business. It's a resilient market outperforming other rental sectors, rapid growth with fairly economic recession-proof and proving relatively resilient during the recent economic crisis. It has been observed, student housing market has consistently been one of the best performing rental sectors during the economic meltdown as the demand was unaffected by other sectors market tumble.

"Ah yes, I think this is true, the rent I am collecting here (student house) is much better than the one I am collecting on residential rental somewhere else in the town. So sure I agreed that student housing rent is better" (Participant 1)

Nigeria like many other countries appeared to be potential for student housing market, considering the rapid growth of HIs student population cohort where $21 \%$ of the total population of 191 million are between the aged of 18-24 years old and over $60 \%$ of the population is under the age of 24 years old. This however, shown the trend of overburdened strong population growth of HIs will continue in the future and will be potential for the development of student housing rental market in the country. Currently an average of 2 million applicants are seeking placement in universities every year that warrant HIs to admit more students that overloaded their housing capacities. Considering incapacitation of HIs to accommodate the teaming student population, $\mathrm{Na}-$ tional Universities Commission (NUC), government agency that oversees the administration of higher education institutions in Nigeria, set up a policy that HIs should only accommodate $33 \%$ of their respective students' population which clearly indicates surging demand in the housing rental market. However, most of the HIs accommodate far less than the proposed $33 \%$ while majority of the students are pushed out to the housing rental market around their HIs neighbourhoods. This is clear testimony that the future demand for higher education institutions and students housing will continue to upsurge hence enrolment overrun HIs student housing facilities suggested continuous future demand is on a high side as the population is increasing. 
The situation will be exacerbating, especially when the HIs student housing stock is not correspondingly run with students enrolment, HIs students' accommodation will obviously remained grossly inadequate. HIs inability to accommodate their growing student population couple with insufficient supply of student housing and a continuing inflow of students resulted to continual increase in demand which created an admirable opportunity for student housing rental market. However, these scenarios create conducive atmosphere for private housing developers to provide student housing in areas where HIs student housing has precipitous shortfalls. The demand indeed, is significant for the private developers to come into the business and the sector is said to be promising and buoyant niche market.

\section{CONCLUSION}

It has been a clear testimony that the demand for higher education spurred up in many countries worldwide and for decades enrolment has been outrunning HIs housing capacity. High student enrolment is the major factor for the student housing demand in the HIs neighbourhoods. It is obvious HIs students housing are grossly inadequate to satisfy the growing demands, majority of the students are pushed out to find alternative housing accommodation in the private housing rental market.

Furthermore, it has been predicted that the global student population will continue to swell up, student housing demand will equally spur up and student housing market will obviously grow which offer opportunity for student housing providers. With this scenario, the student housing is arguably a potential 'alternative' rental market. Indeed Nigeria where there are huge student populations with over $60 \%$ of its total population are under the age of 24 years old and with waves of student housing demand, therefore the market is highly potential. Though the market is 'immature' because most of the private developers are afield in the student housing rental market and the market is dominated by the traditional small scale providers (buy-to-let) who dig into the market and are fetching big dough.

Due to HIs inability to provide enough students housing couple with continuous increase in the student admission yearly in all Nigeria HIs, so filling the gap created by the HIs housing system deficit lies in the hands of the private housing developers. Thus, there is a serious need to adequately provide students housing to ease and curtail students' hassles of getting accommodation to settle and face their academic challenges. Therefore, private housing developers should seize the advantage of dormant supply and increasing demand to make an exceptional outlay in students housing provision as it generated superb opportunity for rental market in order to meet-up with the growing demand. It has been found that student housing is one of the apparent performing rental sectors which produces reliable rental income flow secured by intensity and steadiness of demand which provides a good cash yield and is often correspond with low levels of competing supply. These creates favourable atmosphere for private housing developers to capitalize in a resilient niche market of student housing. It has been observed that private housing developers will contribute to a large proportion of the entire housing stocks for student hence; HIs provide accommodation to only a small segment (20-30\%) of their students' population. Indeed the contribution of private developers in housing provision cannot be underscoring thus they provide accommodation for majority of the students (70-80\%).

\section{ACKNOWLEDGEMENT}

We wish to acknowledge Abubakar Tafawa Balewa University Bauchi, Nigeria for graduate fellowship and special thanks to Nigeria Tertiary Education Trust Fund (TET Fund) for fellowship grant intervention which supported this research.

\section{REFERENCES}

1. Adams, J. (Ed.). (2012). Research methods for graduate business and social science students (8th ed.). Los Angeles: SAGE.

2. Adeleye, O. (2014). An Assessment of Housing Satisfaction among Pre-Degree Students of Obafemi Awolowo University, Ile-Ife, Nigeria. Civil and Environmental Research, 6(8), 169 - 178. 
3. Akingbohungbe, D. O., \& Akinluyi, M. L. (2012). Residents' perception of Off-Campus Student Housing performance in Ili-Ife, Nigeria. Journal of Environmental and Earth Science, 2(7), 69-76.

4. Alaka, I. N., Pat-Mbano, E. C. \& Ewulum, N. J. (2012). Contributions of Private Hostel Providers to Housing Needs of Imo State University Students, at Ugwuorji-Owerri Nigeria. Canadian Social Science, 8(2), 180-186. doi: 10.3968/j.css.1923669720120802.2755

5. Aluko, O. E. (2011). The assessment of housing situation among students in the University of Lagos. African Research Review, 5(3), 104 - 118.

6. Bowden, A., Rivard, N., \& Rose, J. (2011). Student Accommodation in Wembley. Retrieved from https://www.brent.gov.uk/media/3501263/W5.1\%20Student\%20Accommodation\%20in\%20 Wembley\%20(small).pdf

7. Creswell, J. W. (2009). Research design: Qualitative, quantitative, and mixed methods approaches (3rd ed.). Los Angeles: Sage.

8. Donaldson, R., Benn, J., Campbell, M., \& De Jager, A. (2014). Reshaping urban space through studentification in two South African urban centres. Urbani Izziv, 25(Supplement), S176-S188. doi: 10.5379/urbani-izziv-en-2014-25-supplement-013

9. Garg, M., Gupta, K., \& Jha, R. (2014). An empirical study on market research of organized students' housing industry in India. International Journal of ICT and Management, 2(2), 143-154.

10. Garmendia, M., Coronado, J. M., \& Urena, J. M. (2011). University Students Sharing Flats: When studentification Becomes Vertical. Urban Studies, 49(12), 2651-2668. doi: 10.1177/0042098011428176

11. Ghani, Z. A., \& Sulaiman, N. (2016). Theoretical underpinning for understanding student housing. Journal of Environment and Earth Sciences, 6(1), 163-176.

12. Ghani, Z. A., \& Sulaiman, N. (2017). Cash-Cow into the Purse of Malaysian Property Investors: Students Housing Investment. Path of Science, 3(8), 1013-1022. doi: 10.22178/pos.25-5

13. Gopal, P. (2008, March 13). College towns: Still a smart investment. Retrieved from http://www.primepropertyinvestors.com/businessweek.pdf

14. Gray, D. E. (2014). Doing research in the real world (3rd ed.). London: Sage.

15. Hammad, D. B., Musa, J. M., Rishi, A. G., \& Ayuba, I. I. (2013). Criteria for the selection of students' accommodation model in Nigeria tertiary institutions using analytic hierarchy process. Academic Research International, 4(5), 550-556.

16. Hubbard, P. (2009). Geographies of Studentification and Purpose-Built Student Accommodation: Leading Separate Lives? Environment and Planning A, 41(8), 1903-1923. doi: 10.1068/a4149

17. Intelligent Partnership. (n. d.). Student Property: Risks and Reasons to Invest. Retrieved from https://intelligent-partnership.com/research-hub/student-property-risks-reasons-invest

18. Jones Lang LaSalle. (2012). Student housing: a new global asset class. Retrieved from http://www.aninver.com/fotos/file/blog/Global-Student-Housing-Report-November-2012.pdf

19. Jones, H., \& Brown, C. (2013, August). Student Housing Demand and Supply: A review of evidence. Retrieved from http://democracy.leeds.gov.uk/documents/s101308/Student\%20Housing\%20Report\%20App endix\%202\%20210813.pdf

20. Karpinski, M. (2015, March 13). Student accommodation in Malaysia. Retrieved from https://www.hotcoursesabroad.com/study-in-malaysia/student-accommodation/studentaccommodation-in-malaysia/

21. Kenna, T. (2011). Studentification in Ireland? Analysing the impact of students and student accommodation on Cork City. Irish Geography, 44(2-3), 191-213. 
22. Khozaei, F., Ayub, N., Hassan, A. S., \& Khozaei, Z. (2010). The Factors Predicting Students' Satisfaction with University Hostels, Case Study, Universiti Sains Malaysia. Asian Culture and History, 2(2), 148-158. doi: 10.5539/ach.v2n2p148

23. Lewis, J. (2013). Design Issues. In J. Ritchie, J. Lewis, C. Nicholls \& R. Ormston (Eds.), Qualitative research practice: a guide for social science students and researchers (pp. 49-77). Los Angeles: SAGE.

24. Muslim, M. H., Karim, H. A., \& Abdullah, I. C. (2012). Challenges of Off-Campus Living Environment for Non-Resident Students' Well-Being in UiTM Shah Alam. Procedia - Social and Behavioral Sciences, 50, 875-883. doi: 10.1016/j.sbspro.2012.08.089

25. Muslim, M. H., Karim, H. A., \& Abdullah, I. C. (2012). Satisfaction of Students' Living Environment between On-Campus and Off-Campus Settings: A Conceptual Overview. Procedia - Social and Behavioral Sciences, 68, 601-614. doi: 10.1016/j.sbspro.2012.12.252

26. Najib, N. 'Ulyani M., Yusof, N., \& Tabassi, A. A. (2015). Living in On-campus Student Housing: Students' Behavioural Intentions and Students' Personal Attainments. Procedia - Social and Behavioral Sciences, 170, 494-503. doi: 10.1016/j.sbspro.2015.01.052

27. Naoum, S. G. (2007). Dissertation research \& writing for construction students (3rd ed.). New York: Routledge.

28. Omar, D. B., Abdullah, F., Yusof, F., Hamdan, H., Nasrudin, N., \& Abdullah, I. C. (2011). The impacts of off-campus students on local neighbourhood in Malaysia. International Journal of Social, Behavioral, Educational, Economic, Business and Industrial Engineering, 5(10,) 1221-1227.

29. Onwong'a, M. (2012). An assessment of impacts of the growth of hostel accommodation on other land uses: a case study of Ngara west sub-location, Nairobi (Doctoral dissertation, University of Nairobi). Retrieved from http://erepository.uonbi.ac.ke/

30. Pat-Mbano, E. C., Alaka, I. N., \& Okeoma, O. I. (2012). Examining the Physio, Psycho and SocioEconomic Implications of Non-Residential Policy on Imo State University Students. Canadian Social Science, 8(2), 170-179.

31. Population Reference Bureau. (2017). 2017 World population data sheet. Retrieved from http://www.prb.org/pdf17/2017_World_Population.pdf

32. Powley, T. (2013, June 3). How to invest in students property. Financial Times. Retrieved from https://www.ft.com/content/45dde256-cc39-11e2-9cf7-00144feab7de

33. Ritchie, J. (2013). The Applications of Qualitative Methods to Social Research. In J. Ritchie, J. Lewis, C. Nicholls \& R. Ormston (Eds.), Qualitative research practice: a guide for social science students and researchers (pp. 24-46). Los Angeles: SAGE.

34. Rugg, J., Rhodes, D., \& Jones, A. (2000). The nature and impact of student demand on housing markets. York: Joseph Rowntree Foundation.

35. Rugg, J., Rhodes, D., \& Jones, A. (2002). Studying a Niche Market: UK Students and the Private Rented Sector. Housing Studies, 17(2), 289-303. doi: 10.1080/02673030220123234

36. Rutman, S. (2013, March 13). Lesson for investing in student accommodation. Estate Gazette. Retrieved from

http://www.traverssmith.com/media/1298904/lessons_for_investing_in_student_accommodati on.pdf

37. Savills World Research. (2013, Summer). Spotlight European Student Housing. Retrieved from http://pdf.savills.com/documents/European_Student_Spotlight_2013.pdf

38. Savills World Research. (2014, Summer). Spotlight World Student Housing. Retrieved from http://pdf.euro.savills.co.uk/residential---other/spotlight-world-student-housing-2014.pdf

39. Savills World Research. (2016, October 6). Spotlight World Student Housing. Retrieved from http://pdf.euro.savills.co.uk/global-research/spotlight-world-student-housing-2016-2017.pdf 
40. Smith, D. (2012). Studentification: the gentrification factory? Retrieved from https://southwarknotes.files.wordpress.com/2012/03/studentification-darren-smith.pdf

41. Snape, D., \& Spencer, L. (2013). The foundations of qualitative research. In J. Ritchie, J. Lewis, C. Nicholls \& R. Ormston (Eds.), Qualitative research practice: a guide for social science students and researchers (pp. 5-23). Los Angeles: SAGE.

42. Spieler, A., Ong, S. E., \& Petrova, M. (2013). Demand for university student housing: An empirical analysis. Journal of Housing Research, 22(2), 141-164.

43. Stevenson, R., \& Askham, P. (2011). Purpose built student accommodation: changing face of student accommodation in Sheffield. Retrieved from http://shura.shu.ac.uk/11860/1/askham.pdf

44. Student House Business. (2017). The top developers in student housing. Retrieved 5 July, 2017, from http://www.studenthousingbusiness.com/

45. Thomsen, J. (2008). Student Housing - Student homes? Aspects of student housing satisfaction (Doctoral thesis). Retrieved from https://brage.bibsys.no/xmlui/bitstream/handle/11250/231116/124643_FULLTEXT02.pdf?se quence $=1 \&$ isAllowed $=\mathrm{y}$

46. Umaru, E., Abdrazack, N., Aiyenjina, W., \& Ajagbe, M. (2012). The Impacts of Non-Residential Tertiary Institution on Housing in Lagos: A Case Study of Lagos State University. IRACST Engineering Science \& Technology, 2(4), 592-598.

47. Wes, S. (2017, March 7). Education in Nigeria. Retrieved from https://wenr.wes.org/2017/03/education-in-nigeria

48. Wilson, T. D. (2003). Philosophical foundations and research relevance: issues for information research. Journal of Information Science, 29(6), 445-452. doi: 10.1177/0165551503296002

49. Yusuff, O. S. (2011). Students Access to Housing: A Case of Lagos State University Students Nigeria. Journal of Sustainable Development, 4(2). doi: 10.5539/jsd.v4n2p107

50. Zaransky, M. H. (2006). Profit by investing in student housing: Cash in on the campus housing shortage. Chicago: Kalplan Publishing. 